\title{
Helong Language in West Kupang District, Kupang Regency East Nusa Tenggara is Shifting Towards Death
}

\author{
${ }^{1}$ Gregorius Sudaryano, ${ }^{2}$ Made Budiarsa, ${ }^{3}$ I Made Suastra, ${ }^{4}$ Simon Sabon Ola \\ 1. greg.sudaryono@gmail.com STIBA Cakrawala Nusantara Kupang \\ 2.made_budiarsa@yahoo.com Faculty of Arts, Udayana University \\ 3. madesuastra@yahoo.co.id Faculty of Arts, Udayana University \\ 4. sabon_ola@yahoo.com Faculty of Arts, Udayana University
}

\begin{abstract}
Research on language shift related to social factor is included in sociolinguistic research. This study is to examine the phenomenon of Helong language (HL) shift in the District of West Kupang, Kupang Regency, East Nusa Tenggara Province. HL shift is a product of language contact and language competition which is characterized by the use of HL by its speakers that is getting lower and switch to another more prestigious one. Therefore, the phenomenon of HL shift was analyzed based on the choice of HL language use in a domain that implies HL maintenance by its speakers among generations.
\end{abstract}

In order to get the expected data, this study involved 100 respondents consisting groups of 40 parents, 29 adults, and 31 children. The data obtained through data collection techniques were analyzed by using quantitative and qualitative methods. It was conducted based on the attitude of language in the dimensions of language loyalty, language pride, and awareness of language norms in the domains of family, education, customs, neighborhood, government, and religion referring to the level of HL maintenance.

The results showed that the phenomenon of HL shift in the District of West Kupang, Kupang Regency, East Nusa Tenggara Province reflected reducing number of intergenerational Helong native speakers in using their own language. The presence of Indonesian language (IL) intervening the use of language in the domains of education, government, and religion influencing the use of languages in the domains of family and neighborhood. Thus, HL is shifting towards death in the next generations.

Keywords: language maintenance, language shift, language death

\section{Introduction}

Helong language (HL) is one of the Austronesian languages consisting of three dialects, namely Helong Pulau, Helong Darat, and Helong Funai, spoken by about 1,800 members of speech community of Helong who live in parts of the District of West Kupang, Kupang Regency, East Nusa Tenggara Province (Sudaryono, 2011: 44). Considering HL existed among Indonesian language (IL), Dawan language (DL), and Rote language (RL), then the phenomenon 
of language shift and death tends to happen. Edwards (1985: 71-72), one of the phenomena leading to language shift is caused by decreasing number of young speakers to use their own language and switch to another more prestigious one. Furthermore, Crystal (2000: 1-2) stated that a language is considered to shift if there is no more native speakers.

The statement implies that HL shifted since young generation of Helong speech community switch to another more prestigious language instead of HL used in the domains of former language use. The phenomenon of language shift is due to the presence of more prestigious language (IL), intermarriage, communication technology, and migration. The language situation could potentially shift HL towards its death in the future. Therefore, this research focused on the language choice and use in domains of family, education, customs, neighborhood, government, and religion as well as levels of HL maintenance, shift, and death.

\section{Theoretical Background}

Language shift is a language that is not able to sustain itself because it is abandoned by its native speakers. Language maintenance and shift are related to language planning implicate on language choice and use (Eastman, 1983: 32, 142). The phenomenon of language maintenance and shift occur since there is language contact which implies competition among languages (Grosjean 1982). Language competition causes linguistic phenomenon including bilingualism, diglossia, code switching/code-mixing, interference, language shift and death. Language maintenance is closely related to language death implemented in communicative interaction to encourage an effort of surviving a language. If it fails, then the shifting language will slowly lead to death (Sumarsono, 1995: 173).

Language shift and death are caused by the power of majority speech community group against minority, religious and educational backgrounds, social class, intermarriage, policy of government politics on language and the influence of language use patterns (Romaine: 1996). Furthermore, Grosjean (1982: 107) classifies factors of language shift and death into five, namely social, attitudes, language use, government policy, and others.

\section{Research Methods}


This study uses sociolinguistic approach referring to linguistic subject in a social context with the targeted study regarding behavior of speech community group. The study used quantitative and qualitative methods by applying phenomenological framework as its philosophical foundation. In accordance with its appropriate philosophical framework approach, the study was based on factual data found and presented in accordance with reality found when it was conducted (Muhadjir, 1995).

In order to get the expected data, the research involved 100 respondents consisting of 31 children, 29 adults, and 40 parents. The data were obtained through methods of observation, questionnaire, interview, focus group discussions, record, and documentation. To determine the level of language maintenance leading to HL shift and death, the analysis was conducted based on variables of attitudes in dimensions of language loyalty, language pride, and awareness on language norms in the domains of family, education, custom, neighborhood, government, and religion.

\section{Results}

The results of study showing the phenomenon of HL shift and death were obtained by the analysis of language choice and use in the domains of family, education, custom, neighborhood, government, and religion as follows.

\section{Family Domain}

Table 4.1 The Language Use between Adult and Parents /Grandparents/Siblings/Other tenants $(N=29))$

\begin{tabular}{|c|c|c|c|c|c|c|c|c|c|}
\hline No. & Languages & $\begin{array}{l}\text { Grand } \\
\text { parents }\end{array}$ & $\%$ & Parents & $\%$ & Siblings & $\%$ & $\begin{array}{l}\text { Other } \\
\text { tenants }\end{array}$ & $\%$ \\
\hline 1 & $\mathrm{HL}$ & 18 & 62,07 & 9 & 31,03 & 2 & 6,90 & 6 & 20,69 \\
\hline 2 & IL & 4 & 13,79 & 16 & 55,17 & 22 & 75,86 & 17 & 58,62 \\
\hline 3 & HL and IL & 7 & 24,14 & 4 & 13,79 & 5 & 17,24 & 6 & 20,69 \\
\hline 4 & DL & 0 & 0 & 0 & 0 & 0 & 0 & 0 & 0 \\
\hline \multirow[t]{2}{*}{5} & RL & 0 & 0 & 0 & 0 & 0 & 0 & 0 & 0 \\
\hline & Total & 29 & 100 & 29 & 100 & 29 & 100 & 29 & 100 \\
\hline
\end{tabular}

Table 4.1 shows that in family domain, communicative interaction between the speakers of adult group and (1) grandparents used HL 62,07 \%, IL 13,79 \%, HL-IL 24,14 \%, DL $0 \%$, and RL $0 \%$; (2) parents used HL 31,03 \%, IL 55,17 \%, HL-IL 13,79 \%, DL $0 \%$, and RL $0 \%$; (3) 
siblings used HL 6,90 \%, IL 75,86 \%, HL-IL 17,24 \%, DL $0 \%$, and RL $0 \%$; and (4) other tenants used HL 20,69 \%, IL 58,62 \%, HL-IL 20,69 \%, DL $0 \%$, and RL $0 \%$. The quantitative data in Table 4.1 illustrates that the language choice and use of $\mathrm{HL}$ for interaction between the speakers of the adult group and interlocutors of grandparents is still dominant $(62,07 \%)$.

On the other hand, the use of HL for communicative interaction between speakers of adult group and interlocutors of parents group, siblings, and other tenants is shifting that is marked by the speakers who switch to IL in percentage between 55,17 \% and 75,86\%. The use of DL and RL disappears $(0 \%)$ to describe that HL speakers still survive their language in competition among local languages (see Eastman, 1983: 32, 142; Grosjean, 1982). The language situation indicates a reduced number of speakers of adults and children groups of Helong speech communicative to use and switch to IL considered more prestigious one.

Table 4.2 The Language Use between Children and Parents/Grandparents/Siblings/Other tenants $(N=31))$

\begin{tabular}{llrrrrrrrr}
\hline \multirow{2}{*}{ No. } & \multirow{2}{*}{ Languages } & $\begin{array}{c}\text { Grand } \\
\text { parents }\end{array}$ & $\%$ & Parents & $\%$ & Siblings & $\%$ & $\begin{array}{c}\text { Other } \\
\text { tenants }\end{array}$ & \multicolumn{2}{c}{$\%$} \\
\hline 1 & HL & 4 & 12,90 & 2 & 6,45 & 0 & 0 & 1 & 3,23 \\
2 & IL & 21 & 67,74 & 19 & 61,29 & 31 & 100 & 28 & 90,32 \\
3 & HL and IL & 6 & 19,35 & 10 & 32,26 & 0 & 0 & 2 & 6,45 \\
4 & DL & 0 & 0 & 0 & 0 & 0 & 0 & 0 & 0 \\
5 & RL & 0 & 0 & 0 & 0 & 0 & 0 & 0 & 0 \\
& Total & 31 & 100 & 31 & 100 & 31 & 100 & 31 & 100 \\
\hline
\end{tabular}

Data table 4.2 shows the reducing amount of Helong children native speakers when compared with the amount of adult native speakers as shown in the percentages as follows.

Table 4.3 Helong Language Situation in Family Domain

\begin{tabular}{lrrrrrc}
\hline \multicolumn{1}{c}{ Interlocutors } & \multicolumn{4}{c}{ Speakers } & \multicolumn{3}{c}{ Difference } \\
& Adults & \multicolumn{1}{c}{$\%$} & Children & \multicolumn{1}{c}{$\%$} & \multicolumn{1}{c}{ f } \\
\hline Grandparents & 18 & 62,07 & 4 & 12,90 & 14 & 49,17 \\
Parents & 9 & 31,03 & 2 & 6,45 & 7 & 24,58 \\
Siblings & 2 & 6,90 & 0 & 0 & 2 & 6,90 \\
Other tenants & 6 & 20,69 & 1 & 3,23 & 5 & 17,46 \\
\hline
\end{tabular}

Data in table 4.3 shows the difference percentage of reducing number of Helong native speakers using HL in the next generation with grandparents $49,17 \%$, parents $24,58 \%$, siblings $6,90 \%$, and other tenants $17,46 \%$. The reducing number of Helong native speakers of next generation happens in all interlocutors in the domain of family. Based on the above data analysis, the use of HL in family domain can be identified that Helong adult group still use HL to 
communicate with all interlocutors in family domain with: grandparents $62.07 \%$, parents 31,03 $\%$, siblings $6,90 \%$ and other tenants $20,69 \%$, and also children communicate in HL with grandparents $12,90 \%$, parents $6,45 \%$, siblings $0 \%$ and other tenants $3,23 \%$.

Language situation as the result of transferring language from one generation to the next generation appearing in the table shows that the use HL in the domain of family is shifting. That is, older native speakers still use their language but the amount of native speakers using HL reduces from generation to generation. Thus, HL will be possible to die in the future.

\section{Education Domain}

Table 4.4 The Language Use between Children (students) and Schoolmates, Teachers, and School Officers $(N=29+31=60)$

\begin{tabular}{|c|c|c|c|c|c|c|}
\hline Languages & Schoolmates & $\%$ & Teachers & $\%$ & School Officers & $\%$ \\
\hline $\mathrm{HL}$ & 0 & 0 & 0 & 0 & 0 & 0 \\
\hline IL & 49 & 81,67 & 60 & 100 & 60 & 100 \\
\hline HL-IL & 11 & 18,33 & 0 & 0 & 0 & 0 \\
\hline DL & 0 & 0 & 0 & 0 & 0 & 0 \\
\hline RL & 0 & 0 & 0 & 0 & 0 & 0 \\
\hline Total & 60 & 100 & 60 & 100 & 60 & 100 \\
\hline
\end{tabular}

Table 4.4 describes the communicative interaction between students and interlocutors: schoolmates using HL $0 \%$, IL 81,67 \%, HL-IL 18,33 \%, DL $0 \%$, and RL $0 \%$; teachers using HL $0 \%$, IL $100 \%$, HL-IL $0 \%$, DL $0 \%$, and RL $0 \%$; school officers using HL $0 \%$, IL100 \%, HL-IL $0 \%$, DL $0 \%$, and RL $0 \%$. Overall, the data shows that HL is in shifting process which is characterized by Helong native speakers switch to IL to interact socially.

\section{Neighborhood Domain}

Tabel 4.5 The Language Use between Speakers of Parents and the Same Age, Older, and Younger Neighbors $(N=40)$

\begin{tabular}{lrrrrrr}
\hline \multicolumn{1}{c}{ Languages } & $\begin{array}{c}\text { The same age } \\
\text { neighbors }\end{array}$ & $\%$ & $\begin{array}{c}\text { Older } \\
\text { neighbors }\end{array}$ & $\%$ & $\begin{array}{c}\text { Younger } \\
\text { neighbors }\end{array}$ & \multicolumn{1}{c}{$\%$} \\
\hline HL & 34 & 85 & 34 & 85 & 27 & 67,50 \\
IL & 0 & 0 & 0 & 0 & 3 & 7,50 \\
HL-IL & 6 & 15 & 6 & 15 & 10 & 25 \\
DL & 0 & 0 & 0 & 0 & 0 & 0 \\
RL & 0 & 0 & 0 & 0 & 0 & 0 \\
Total & 40 & 100 & 40 & 100 & 40 & 100 \\
\hline
\end{tabular}

Table 4.5 describes language situation in neighborhood domain involving Helong parents and interlocutors: the same age neighbors using HL $85 \%$, IL $0 \%$, HL-IL $15 \%$, DL $0 \%$, and RL 
$0 \%$; older neighbors using HL $85 \%$, IL $0 \%$, HL-IL $15 \%$, DL $0 \%$, and RL $0 \%$; younger neighbors using HL $67 \%$, IL 7,5\%, HL-IL $25 \%$, DL $0 \%$, and RL $0 \%$. Thus, it shows that the language situation of Helong parents still maintain HL well in neighborhood domain.

Table 4.6 The Language Use between Adults and the Same Age, Older, and Younger Neighbors $(N=29)$

\begin{tabular}{lrrrrrr}
\hline \multicolumn{1}{c}{ Languages } & $\begin{array}{c}\text { The same age } \\
\text { neighbors }\end{array}$ & \multicolumn{1}{c}{$\begin{array}{c}\text { Older } \\
\text { neighbors }\end{array}$} & \multicolumn{3}{c}{$\begin{array}{c}\text { Younger } \\
\text { neighbors }\end{array}$} & \multicolumn{1}{c}{$\%$} \\
\hline HL & 7 & 24,14 & 24 & 82,76 & 0 & 0 \\
IL & 13 & 44,83 & 3 & 10,34 & 23 & 79,31 \\
HL-IL & 9 & 31,03 & 2 & 6,90 & 6 & 20,69 \\
DL & 0 & 0 & 0 & 0 & 0 & 0 \\
RL & 0 & 0 & 0 & 0 & 0 & 0 \\
Total & 29 & 100 & 29 & 100 & 29 & 100 \\
\hline
\end{tabular}

Table 4.6 describes the language situation in the domain of neighborhood involving Helong adult speakers and interlocutors of: the same age neighbor using HL 24, $14 \%$, IL 44,83 \%, HL-IL $31,03 \%$, DL $0 \%$, and RL $0 \%$; Older neighbors using HL 82,76 \%, IL 10,34 \%, HL-IL 6,90 \%, DL $0 \%$, and RL $0 \%$; younger neighbors using HL $0 \%$, IL 79,31 \%, HL-IL 20,69 \%, DL $0 \%$, and RL $0 \%$. Therefore, table 4.6 shows that the language situation of Helong is shifting which marked by Helong adult switch to using IL for social interaction in the domain of neighborhood.

Tabel 4.7 The Language Use between Children and the Same Age, Older, and Younger Neighbors $(N=31)$

\begin{tabular}{lrrrrrr}
\hline Languages & $\begin{array}{c}\text { The same age } \\
\text { neighbors }\end{array}$ & \multicolumn{2}{c}{$\begin{array}{c}\text { Older } \\
\text { neighbors }\end{array}$} & \multicolumn{3}{c}{$\begin{array}{c}\text { Younger } \\
\text { neighbors }\end{array}$} \\
\hline HL & 0 & 0 & 0 & 0 & 0 & 0 \\
IL & 29 & 93,55 & 29 & 93,55 & 31 & 100 \\
HL-IL & 2 & 6,45 & 2 & 6,45 & 0 & 0 \\
DL & 0 & 0 & 0 & 0 & 0 & 0 \\
RL Total & 0 & 0 & 0 & 0 & 0 & 0 \\
$\quad$ & 31 & 100 & 31 & 100 & 31 & 100 \\
\hline
\end{tabular}

Table 4.7 describes the language situation in domain of neighborhood involving Helong children and interlocutors: the same age neighbors using HL $0 \%$, IL 93,55 \%, HL-IL 6,45 \%, DL $0 \%$, and RL $0 \%$; older neighbors using HL $0 \%$, IL $93 \%$, HL-IL 6,45 \%, DL $0 \%$, and RL 0 $\%$; younger neighbors using HL $0 \%$, IL $100 \%$, HL-IL $0 \%$, DL $0 \%$ and RL $0 \%$. Thus, table 4.7 shows that the language situation in Helong children group is shifting which is marked by children do not use HL for social interaction in neighborhood domain except in the context of code-mixing or code switching (HL-IL) showed in the percentage of $6,45 \%$. 


\section{Domain of Religion}

Christian is the majority of Helong community members in West Kupang District, Kupang Regency. It has an important role in social life of the community. In religious activities, IL is the only language used in the region influencing HL situation. Therefore, the analysis referred to the opinion stated out by members of the community in the statements of strongly disagree, disagree, just agree-never mind, and abstain if $\mathrm{HL}$ is used in the domain. The statements determine behavior of Helong speakers to their own language in the dimension of language loyalty, language pride, and the awareness of language norms based on the language choice and use in appropriate domains.

Tabel 4.8 The Agreement and Disgreement by Helong Parents on the Use of HL for Religious Speeches $(N=40)$

\begin{tabular}{lcrr}
\hline & Statements & $\mathrm{f}$ & \multicolumn{1}{c}{$\%$} \\
\hline Strongly disagree & & 3 & 7,50 \\
Disagree & & 19 & 47,50 \\
Just agree, never mind & & 16 & 40 \\
Abstain & Total & 2 & 5 \\
& & 40 & 100 \\
\hline
\end{tabular}

Table 4.8 describes positive behavior of Helong parents to their language $55 \%$ (strongly disagree 7,50 \% and disagree 47,50\%), and negative attitudes to their language $40 \%$ (just agree, never mind). HL situation in the parents group showed that HL is shifting.

Tabel 4.9 The Agreement and Disgreement by Helong Adults on the Use of HL for Religious Speeches $(N=29)$

\begin{tabular}{lcrr}
\hline & Statement & $\mathrm{f}$ & \multicolumn{1}{c}{$\%$} \\
\hline Strongly disagree & & 3 & 10,34 \\
Disagree & & 13 & 44,83 \\
Just agree, never mind & & 12 & 41,38 \\
Abstain & Total & 1 & 3,45 \\
& & 29 & 100 \\
\hline
\end{tabular}

Table 4.9 describes positive behavior of adult speakers of Helong to their language $55,17 \%$ (strongly disagree 10,34\% and disagree 44,83\%), and negative attitudes to their language 41,38 $\%$ (just agree, never mind). HL situation in the adult group also showed that HL is shifting. 
Tabel 4.10 The Agreement and Disgreement by Helong Children on the Use of HL for Religious Speeches $(N=31)$

\begin{tabular}{lcrr}
\hline & Statements & $\mathrm{f}$ & \multicolumn{1}{c}{$\%$} \\
\hline Strongly disagree & & 0 & 0 \\
Disagree & & 27 & 87,10 \\
Just agree, never mind & & 4 & 12,90 \\
Abstain & Total & 0 & 0 \\
& & 31 & 100 \\
\hline
\end{tabular}

Table 4.10 describes positive behavior of HL children speakers to their language only 12,90 $\%$ (just agree, never mind) and negative attitudes to their language 87,10\%. Language situation of HL in children group also showed that HL is shifting.

\section{Domain of Custom}

In the socio-cultural aspect, Helong community still adhere to the traditions and customs which indirectly implies high language loyalty of HL native speakers especially the older generation. The proof shows that Helong community is still very concerned with their traditions consistently to conduct traditional ceremonies consistently, such as traditional wedding, pregnancy, birth, death, and agriculture ceremonies. In every conducted ceremony, traditional leaders always use HL for customary ritual speech because semantically, ritual speech cannot be changed by other languages. Data on table 4.11 were obtained by the recognitions of respondents about the use of language in the domain of custom.

Tabel 4.11 The Language Use $(N=100)$

\begin{tabular}{|c|c|c|c|c|c|c|c|c|c|c|}
\hline \multirow{2}{*}{$\begin{array}{l}\text { Traditional } \\
\text { Ceremony }\end{array}$} & \multicolumn{10}{|c|}{ Languages } \\
\hline & HL & $\%$ & IL & $\%$ & HL-IL & $\%$ & DL & $\%$ & RL & $\%$ \\
\hline Wedding & 100 & 100 & 0 & 0 & 0 & 0 & 0 & 0 & 0 & 0 \\
\hline Pregnancy & 100 & 100 & 0 & 0 & 0 & 0 & 0 & 0 & 0 & 0 \\
\hline Birth & 100 & 100 & 0 & 0 & 0 & 0 & 0 & 0 & 0 & 0 \\
\hline Death & 100 & 100 & 0 & 0 & 0 & 0 & 0 & 0 & 0 & 0 \\
\hline Agriculture & 100 & 100 & 0 & 0 & 0 & 0 & 0 & 0 & 0 & 0 \\
\hline
\end{tabular}

Table 4.11 describes that the language situation in custom domain does not enable any other language (IL, DL and RL) to be used in ritual speech of Helong traditions. HL is the only language used for ritual ceremonies of marriage, pregnancy, birth, death, and agriculture (shown in the percentage of $100 \%$ ). Thus, in the custom domain, Helong native speakers still maintain 
their language well. Nevertheless, Helong customary ritual speech can only be performed by some indigenous leaders implies that such ability only possessed by several older speakers, and then it is possible that HL in the domain will be shifting in the future. The statement was logically since most domains show HL has been shifted by IL.

\section{Conclusion}

Language contact involving IL and other local languages that implies language competition makes HL situation instable. It shows linguistic phenomena in which Helong native speakers inconsistently use HL in most domains. Inconsistency of HL use indicates weakness of language maintenance and negative attitudes of young generation of Helong speech community to their own language. Therefore, the unbalanced language choice and use tend to shift HL because the young generation of Helong switch to IL which is considered more prestigious than HL to interact socially in most domains of language use.

The intervention of IL used dominantly hinders HL maintenance and development among Helong younger generation. The results of the study show phenomenon of HL shift towards its death which is characterized by a reduce in the number of Helong native speakers from generation to generation using their own language in the domains of family and neighborhood as follows.

\begin{tabular}{crrrrrrrrr}
\hline \multicolumn{6}{c}{ The percentages of Helong Native Speakers Who Use HL in Family Domain } \\
Group & $\begin{array}{c}\text { Grand } \\
\text { parents }\end{array}$ & $\%$ & Parents & $\%$ & Siblings & $\%$ & Other & tenants & $\%$ \\
\hline Adults & 18 & 62,07 & 9 & 31,03 & 2 & 6,90 & 6 & 20,69 \\
Children & 4 & 12,90 & 2 & 6,45 & 0 & 0 & 1 & 3,23 \\
\hline
\end{tabular}

The percentages of Helong Native Speakers Use Who HL in Neighborhood Domain

\begin{tabular}{crrrrrr}
\hline Group & $\begin{array}{c}\text { The same age } \\
\text { neighbors }\end{array}$ & \multicolumn{2}{c}{$\begin{array}{c}\text { Older } \\
\text { neighbors }\end{array}$} & $\%$ & $\begin{array}{c}\text { Younger } \\
\text { neighbors }\end{array}$ & $\%$ \\
\hline Parents & 34 & 85 & 34 & 85 & 27 & 67,50 \\
Adults & 7 & 24,14 & 24 & 82,76 & 0 & 0 \\
Children & 0 & 0 & 0 & 0 & 0 & 0 \\
\hline
\end{tabular}




\section{References}

Crystal, David.2000. Language Death. United Kingdom: Cambridge University Press.

Eastman, Carol M. 1983. Language Planning: An Introduction. San Fransisco \& Sharp

Edwards, John. 1985. Language, Society, and Identity. Oxford: Basil Blackwell.

Grosjean, Francois. 1982. Life with Two Language: An Introduction to Bilingualism. Cambridge: Harvard University Press.

Muhadjir, Noeng.1995. Metodologi Penelitian Kualitatif; Telaah Positivistik, Rasionalistik, Phenomenologik, Realisme Methaphisik. Yogyakarta: Rake Sarasin.

Romaine, Suzanne. 1996. Bilingualism, Handbook of Second Language Acquisition. San Diego, CA: Academic Press.

Sudaryono, Gregorius. 2011. Pemertahanan Bahasa Helong di Desa Oematnunu, Kecamatan Kupang Barat, Kabupaten Kupang. Tesis S2 Universitas Nusa Cendana.

Sumarsono. 1995. Pemertahanan Bahasa Melayu Loloan di Bali. Jakarta Pusat Pembinaan dan Pengembangan Bahasa. 